Dominik J. Kościuk

University of Bialystok, Poland

ORCID: 0000-0002-2695-8212

d.kosciuk@uwb.edu.pl

Justyna Kulikowska-Kulesza

University of Bialystok, Poland

ORCID: 0000-0001-6934-9014

j.kulikowska@uwb.edu.pl

\title{
The Right to Public Information. Selected Interpretation Doubts in the Doctrine and Jurisprudence of Administrative Courts
}

\author{
Prawo do informacji publicznej. Wybrane wątpliwości \\ interpretacyjne $w$ doktrynie i orzecznictwie sądów administracyjnych
}

\section{SUMMARY}

The provisions of the Act on Access to Public Information regulate, among others, the subjective and objective scope of the right to public information, reasons for restricting access to information, procedure and form of disclosure, rules for creating and publishing information in the Public Information Bulletin, costs of activities leading to the disclosure of information and the establishment of complaint proceedings in the event of refusal to provide the public information requested. Therefore, it is worth to pay attention to several problems arising from the analysis of statutory provisions and the practical consequences of applying the Act of 6 September 2001 on Access to Public Information. The current, extremely extensive, output of doctrine and jurisprudence allows for a fairly "efficient" summary of the considerations made in both literature and judicial and administrative case law.

Keywords: public information; transformed information; public official

The right to public information in the Republic of Poland has been guaranteed in Article 61 (1) of the Constitution of the Republic of Poland. The provision states that a citizen shall have the right to obtain information on the activities of organs 
of public authority as well as persons holding public functions. Such right shall also include receipt of information on the activities of self-governing economic or professional authorities and other persons or organizational units relating to the field in which they perform the duties of public authorities and manage communal assets or property of the State Treasury. The legislator has included in detail the above "rule" in Article 61 (2) of the Polish Constitution. It is indicated there that the right to obtain information shall cover access to documents and entry to sittings of collective units of a public authority formed by universal elections, with the opportunity to make sound and visual recordings.

While the Constitution of the Republic of Poland sets out the general principle of making public information available, we can find its specification in the Act of 6 September 2001 on Access to Public Information ${ }^{1}$. The provisions of this normative act regulate, among others, the subjective and objective scope of the right to public information, reasons for restricting access to information, procedure and form of disclosure, rules for creating and publishing information in the Public Information Bulletin, costs of activities leading to the disclosure of information and the establishment of complaint proceedings in the event of refusal to provide the public information requested.

Therefore, it is worth to pay attention to several problems arising from the analysis of statutory provisions, as well as the practical consequences of applying the Act on Access to Public Information. The current, extremely extensive, output of doctrine and jurisprudence allows for a fairly "efficient" summary of the considerations made in both literature and judicial and administrative case law.

First of all, it should be noted that in accordance with the provision of Article 1 (1) of the Act on Access to Public Information, any information on public matters constitutes public information within the meaning of the Act and is a subject to disclosure and use on the terms and in the mode specified in that Act. Details of the above standard can be found in Article 6 of the Act on Access to Public Information. From its content one can distinguish three areas of information, the disclosure of which is the responsibility of public entities. These include information on: 1) the actions of authorities and other public entities; 2) public data; and 3) public property.

According to the "open" (by using the phrase "in particular") nature of this provision, the first of the above-mentioned areas of information provided should include information on: internal and foreign policy (including intentions of legislative and executive power, designing normative acts, programs for the implementation of public tasks, how to implement them, performance and effects of these tasks);

Journal of Laws 2019, item 1429.

2 The term "in particular" determines the open, incomplete nature of the specification contained therein. See R. Stefanicki, Ustawa o dostępie do informacji publicznej. Wybrane zagadnienia w świetle orzecznictwa sądowego, „Państwo i Prawo” 2004, z. 2, p. 98. 
public authority units, professional and economic self-governments, entities representing the State Treasury and local self-government, trade unions and political parties (including their legal status or legal form, organization principles, subject of activity and competences, units and persons performing functions in them and their competences, ownership structure and assets at their disposal); rules of functioning of public authorities (including the mode of their operation in the performance of public tasks and their activities within the budgetary and non-budgetary economy, ways of establishing public law acts, ways of accepting and settling matters, the state of accepted matters, the order of their settlement or settlement, registers kept, records and archives, and about the ways and principles of sharing the data contained therein, the recruitment of candidates for employment for vacancies, to the extent specified in separate provisions, choosing candidates for a senior position in the civil service, to the extent specified in separate provisions).

The second area can be identified as a public data information. This includes the content of official documents, in particular: administrative acts and other decisions, documentation of the course and effects of inspections (as well as statements, positions, applications and opinions of entities conducting it), judgements of common courts, the Supreme Court, administrative courts, military courts, the Constitutional Tribunal and the State Tribunal. The provision of Article 6 of the Act on Access to Public Information also indicates the data contained in positions in public matters taken by public authorities and public officials within the meaning of the provisions of the Penal Code, the content of other motions and assessments made by public authorities and information on the condition of the state, local governments and their organizational units.

The third area in the above-mentioned ones constitutes information on public property, including: assets and liabilities of the State Treasury and its organizational units, local government, revenues and losses of commercial companies, public debt, elements of public aid and public burdens.

Therefore, it can be assumed that public information will be any message created or referred to public authorities, as well as generated or referred to other entities performing public functions in the scope of performing public authority tasks and managing municipal property or property of the State Treasury. It is the content of documents created by public authorities and other entities performing public tasks. The content of motions and assessments, regardless of which entity they are addressed to and which matters they are relate to. Therefore, public information is the content of all kinds of documents relating to a unit of public authority in the broad sense, related to a unit or in any way concerning the unit, regardless of what the subject matter is. These are both the content of documents directly produced by the authority unit and those that the unit uses to carry out its statutory tasks, including those that only partly relate to the unit even if it does not come directly from it. On the other hand, requests for individual cases, requests to initiate proceedings 
in another case, as well as requests for future actions of authorities in individual cases do not have the nature of public information ${ }^{3}$.

Considering the above, it cannot be stated that if specific information was not indicated in Article 6 (1) of the Act on Access to Public Information, it does not constitute public information. According to the well-established standpoint of jurisprudence, an entity obliged to provide public information should always apply the general principles contained in Articles $1-5$ of this Act, having in mind above all the principle of universal access to public information ${ }^{4}$. If this entity had any doubts as to whether the information requested falls within the scope of the provisions of the Act on Access to Public Information, it should - in accordance with the demands of the Supreme Administrative Court - interpret the provisions in favour of the person exercising the right to such information ${ }^{5}$. Identical conclusions result from the doctrine analysis. For example, I. Kamińska and M. Rozbicka-Ostrowska wrote that:

[...] the catalogue contained in Article 6 of the Act, however, is relevant to determining what information is to be mandatory in the Public Information Bulletin. This provision does not enumerate the types of public information, but only certain categories of it subject to specific disclosure, which results directly from Article 8 (3) of the commented $\mathrm{Act}^{6}$.

M. Jabłoński also noted that "the classification of specific information as being subject to disclosure within the meaning of the Act is determined by the material criterion, i.e. the content and nature of the information, and not the subjective criterion, which in the discussed act is also not enumerative"

Such a broadly defined subjective and objective right to obtain public information - contrary to the legislator's expectation - did not lead to the elimination of interpretative doubts in the practice of applying the provisions of the Act on Access to Public Information. At the same time - in order to organize the analysis - it

3 The above conclusion can be drawn by analysing the following judgements of administrative courts: judgement of the Voivodeship Administrative Court in Warsaw of 18 January 2019, II SAB/ Wa 612/18; judgement of the Supreme Administrative Court of 14 April 2017, I OSK 872/15; decision of the Supreme Administrative Court of 11 December 2002, II SAB 105/02, LEX No. 137863; judgement of the Voivodeship Administrative Court in Warsaw of 22 June 2007, II SAB/Wa 175/06, LEX 340013; judgement of the Voivodeship Administrative Court in Warsaw of 24 March 2006, II SAB/Wa 1/06, LEX 197599.

4 See judgement of the Supreme Administrative Court in Wrocław of 5 December 2002, II SA/ Wr 1600/02.

5 See judgement of the Supreme Administrative Court of 2 July 2003, II SA 837/03.

6 I. Kamińska, M. Rozbicka-Ostrowska, Komentarz do art. 6 ustawy o dostępie do informacji publicznej, LEX/el. An identical opinion is expressed by P. Sitniewski (Ustawa o dostępie do informacji publicznej. Komentarz, Wrocław 2011, p. 117).

7 M. Jabłoński, Wejście w życie ustawy o dostępie do informacji publicznych, „Przegląd Prawa i Administracji” 2002, nr 51, p. 231. 
should be emphasized that since the role of this article is not to clarify all doubts arising in the practice of applying the Act on Access to Public Information, so - as an example - we will present only a small part of existing interpretation problems.

Therefore, it is worth paying attention to the emerging question whether the subject of a request for access can only be information about the facts or intentions (activities in a more specific or indefinite future) of the authority. It is claimed in the doctrine and case law that Article 6 (1) of the Act on Access to Public Information shows that:

[...] not all future activities of the authority are of this nature, but only those that relate to the intentions of the legislative and executive authority on internal and foreign policy, on the design of normative acts and programs in the implementation of public tasks, the manner of their implementation and the implementation and the effects of these tasks ${ }^{8}$.

It is apparent, therefore, that these "intentions" can relate only to:

$[\ldots]$ general matters, which take the form of already adopted programs or intentions in the area of legislative activities or activities in the sphere of state policy or other public bodies. However, this applies to information already existing at the time the information is provided, not to any intentional intent to take specific actions 9 .

Another question that the jurisprudence is trying to answer relates to finding whether universal access to public information is unconditional and absolute. This problem is so significant that - in accordance with Article 5 (2) of the Act on Access to Public Information - the right to public information is restricted due to the privacy of the natural person or the secret of the entrepreneur, but this restriction does not apply to information about persons holding public functions related to holding these functions, including the conditions of entrusting and holding functions, and the case when a natural person or entrepreneur resign from their right.

It is, therefore, necessary to first determine the meaning of the expression "a person holding a public function". The key aspect in this regard seems to be one of the judgements of the Constitutional Tribunal, which stated:

In an attempt to indicate the general characteristics that will determine that a given entity holds a public function, it can be concluded without greater risk or error, that these are such positions and functions whose exercise is tantamount to taking actions that directly affect the legal situation of others, or involves at least preparing decisions about other people. Therefore, such positions, even those held within public authorities, which are of a service or technical nature are excluded from the scope of public function ${ }^{10}$.

${ }^{8}$ I. Kamińska, M. Rozbicka-Ostrowska, op. cit.

9 Judgement of the Supreme Administrative Court of 20 June 2002, II SAB 70/02. Similarly: judgement of the Voivodeship Administrative Court in Gdańsk of 5 June 2019, II SAB/Gd 34/19.

${ }_{10}$ See judgement of the Constitutional Tribunal of 20 March 2006, K 17/05. 
Confirmation of the above is also obtained from the analysis of administrative court judgements. For example, the Voivodeship Administrative Court in Gdańsk stated that:

[...] doctrine and case law are of the opinion that a person performing a public function within the meaning of the Act is undoubtedly a public official within the meaning of Article $115 \S 13$ of the Penal Code, but the term based on Article 5 (2) of the Act should be understood more broadly. Pursuant to the Act on Access to Public Information, a person holding a public function will be anyone who performs a function in units of public authority or in the structures of any legal persons and organizational units without legal personality, if this function is related to the management of state or local property or management of matters related to the performance of their tasks by public authorities, as well as other entities that implement this authority or management of municipal property or property of the State Treasury. Public function is performed by people who perform the tasks entrusted to them by state institutions or local governments and, thus, gain significant influence on the content of decisions of a general nature. The feature that distinguishes a person who performs a public function is having a specific scope of rights that allows shaping the content of tasks performed in the public sphere ${ }^{11}$.

It is also worth citing the judgements of the Voivodeship Administrative Court in Kraków, in which this court noticed that:

[...] having even a narrow scope of decision-making powers exercised within the framework of an employing public institution may indicate that in a particular case a given person may perform public functions. The presented considerations lead to the conclusion that due to the scope of duties of the managers of specific organizational units of the Marshal's Office indicated above, it is reasonable to state that these entities have at least a connection with holding public functions within the meaning of Article 5 (2) of the Act on Access to Public Information, because by being the head of a specific organizational unit of the Marshal's Office they have a real impact on the management of such entity's matters related to the public sphere ${ }^{12}$.

It follows from the above that the concept of "holding a public function" presented in this way is extremely broad and does not allow the exclusion of too many functions in public administration. In practice, only service and technical positions are subject to such exclusion, for instance: cleaner, archivist, IT specialist, driver, reception desk staff, security guard, technical service employee, secretary, etc. Undoubtedly, such positions, even those held within public authorities, which are of a service or technical nature are excluded from the scope of public function. On

${ }^{11}$ See judgement of the Voivodeship Administrative Court in Gdańsk of 11 June 2014, II SA/ Gd 5/14. See also judgement of the Supreme Administrative Court of 13 October 2016, I OSK 3451/15; judgement of the Voivodeship Administrative Court in Gliwice of 29 March 2004, II SAB/ Ka 144/03; judgement of the Voivodeship Administrative Court in Gdańsk of 11 September 2013, II SA/Gd 503/13.

${ }^{12}$ See judgement of the Voivodeship Administrative Court in Kraków of 2 September 2014, II $\mathrm{SA} / \mathrm{Kr} 940 / 14$. 
the other hand, service or technical activities should be related to tasks that do not involve any powers.

At this point, it is advisable to note that the case law of administrative courts is in favour of open spending of public funds allocated to the remuneration of persons holding public functions. This view was approved in: the judgement of the Supreme Administrative Court of 16 November 2017 (I OSK 94/16); the judgement of the Voivodeship Administrative Court in Kielce of 6 March 2013 (II SAB/Ke 3/13); the judgement of the Voivodeship Administrative Court in Wrocław of 25 October 2012 (IV SA/Wr 383/12) - regarding the remuneration of the chancellor of a university; the judgement of the Voivodeship Administrative Court in Warsaw of 8 November 2010 (II SAB/Wa 204/10), the judgement of the Voivodeship Administrative Court in Warsaw of 14 December 2012 (II SAB/Wa 246/11), the judgement of the Voivodeship Administrative Court in Warsaw of 7 July 2011 (VIII SAB/Wa 23/11) - regarding the remuneration of the commune head and other local government employees; the judgement of the Voivodeship Administrative Court in Warsaw of 8 November 2010 (II SAB/Wa 204/10) - regarding the remuneration of city guard employees; the judgement of the Voivodeship Administrative Court in Warsaw of 11 October 2013 (II SAB/Wa 298/13), the judgement of the Voivodeship Administrative Court in Warsaw of 15 April 2014 (II SAB/Wa 97/14), the judgement of the Voivodeship Administrative Court in Warsaw of 5 March 2014 (II SAB/Wa 730/13) - regarding the remuneration of ministry spokesmen ${ }^{13}$.

Despite such a "broad" definition of "a person holding a public function", and therefore a fairly "extensive" right to information generated by such persons, it is impossible not to pay attention to the provision of Article 5 (2) sentence 1 of the Act on Access to Public Information. It stipulates that the right to public information is limited, among others, because of the privacy of a natural person. Although the provisions of the Act on Access to Public Information do not include the definition of "privacy of a natural person", issues related to limiting access to public information due to the protection of the privacy of a natural person require establishing the relationship in which the provisions of the Act on Access to Public Information and Regulation (EU) 2016/679 of the European Parliament and of the Council of 27 April 2016 on the protection of natural persons with regard to the processing of personal data and on the free movement of such data, and repealing Directive 95/46/EC (General Data Protection Regulation) ${ }^{14}$. Thus, it should be noted that making public information available is the responsibility of entities performing public tasks arising from legal provisions (in particular from Article 1 (1), Article 2 (1) and Article 4 of the Act on Access to Public Information) and public subject law

${ }^{13}$ All listed judgements are available on the websites of the Central Database of Administrative Court Judgements - http://orzeczenia.nsa.gov.pl.

${ }^{14}$ OJ EU L 2016.119.1 of 4 May 2016, hereinafter: GDPR. 
arising from Article 61 (1) of the Polish Constitution, and Article 2 (1) of the Act on Access to Public Information. In turn, according to Article 6 (1) GDPR, processing is lawful only if and to the extent that one or more of the following conditions are met: a) the data subject has consented to the processing of his or her personal data for one or more specified purposes; b) processing is necessary for the performance of a contract to which the data subject is party or to take action at the request of the data subject before the conclusion of the contract; c) processing is necessary to fulfil the legal obligation incumbent on the controller; d) processing is necessary to protect the vital interests of the data subject or of another natural person; e) processing is necessary for the performance of a task carried out in the public interest or in the exercise of official authority vested in the controller; f) processing is necessary for the purposes of legitimate interests pursued by the controller or by a third party, except for situations where the interests or fundamental rights and freedoms of the data subject, requiring personal data protection, prevail over those interests especially if the data subject is a child. This means that, in accordance with the GDPR, disclosure of public information is permissible according to the principles set out in this normative act, when it is necessary to perform a task carried out in the public interest or as part of exercising public authority entrusted to the controller. There is no doubt, however, that sharing public information is for public purposes.

The aboved shown interpretation seems to be consistent with the findings of the European Court of Human Rights (ECHR). For example, the Court - in the case of Magyar Helsinki Bizottság (Hungarian Helsinki Committee) vs Hungary ${ }^{15}$, where Magyar Helsinki Bizottság, a non-governmental organization monitoring the implementation of compliance with international human rights instruments, asked police units to disclose the names of defenders granted ex officio in criminal proceedings together with an indication the number of cases related to them and no such data was obtained - he concluded that Article 10 of the European Convention on Human Rights justifies the disclosure of the names of public defenders despite the fact that such information constitutes personal data. According to the ECHR, the activities of public defenders could not be considered as private activity.

The principle of providing public information is also subject to restrictions due to (as indicated in Article 5 (2) of the Act on Access to Public Information) business secret. It is, therefore, necessary to clarify what that secret is, given that the concept of "business secret" raises doubts.

It is worth noting, therefore, that the Polish legal system uses the term "business secret", which can be used at least as an alternative to the interpretation of the term

15 Judgement of the European Court of Human Rights of 8 November 2016, Magyar Helsinki Bizottság (Hungarian Helsinki Committee) vs Hungary, Application No. 18030/11, https://hudoc. echr.coe.int/eng\#\{\%22itemid\%22:[\%22001-167828\%22]\} [access: 4.12.2019]. 
"entrepreneur's secret". The concept of "business secret" is defined in Article 11 (4) of the Act of 16 April 1993 on Combating Unfair Competition ${ }^{16}$, as undisclosed technical, technological, organizational enterprise information or other information of economic value on which the entrepreneur has taken the necessary measures to maintain its confidentiality. A similar understanding of the entrepreneur's secret is found in applicable administrative court judgements. For example, the Supreme Administrative Court in judgement of 5 July $2013^{17}$ stated that the entrepreneur's secret consists of two elements: material (e.g. detailed description of how the service was performed, its cost) and formal (the will to keep the given information secret). The entrepreneur's secret is derived from the business secret and these concepts generally overlap, although the entrepreneur's secret may in some cases be understood more broadly. The entrepreneur's secret is information known only to a specific group of people and related to the business conducted by the entrepreneur, for which he has taken sufficient protection measures to keep it confidential (no condition of the economic value of information is required, as in the case of business secret). Information becomes a "secret" when an entrepreneur wishes to keep it as unknowable to third parties. However, it does not lose its character due to the fact that a limited group of people obliged to discretion know about it (e.g. company employees). Maintaining information as a secret requires the entrepreneur to take action to eliminate the possibility of third parties accessing them in the normal course of events, without requiring special efforts ${ }^{18}$. A somewhat more specific (due to clearly indicated conditions) definition of a trade secret was formulated by the Voivodeship Administrative Court in Warsaw stating that in order to recognize certain information as a trade secret, it should meet three conditions. First, it cannot be disclosed to the public beforehand. Secondly, it should have technical, technological, organizational character or have economic value. Thirdly, the entrepreneur should take the necessary measures to maintain confidentiality of such information ${ }^{19}$.

It is also noticeable that the restriction of access to public information due to the entrepreneur's secret may occur only when the entity obliged to disclose shows that the information requested is actually the entrepreneur's secret. In accordance with the applicable case-law of administrative courts, the reservation of secret is an exception to the principle of public disclosure and, therefore, the entity obliged to disclose it may not limit itself to a mere statement on the existence of such secret ${ }^{20}$.

16 Journal of Laws 2019, item 1010 as amended.

17 I OSK 511/13.

18 See judgement of the Supreme Administrative Court of 2 July 2003, II SA 837/03.

19 See judgement of the Supreme Administrative Court of 7 March 2019, I OSK 888/17; judgement of the Voivodeship Administrative Court in Warsaw of 15 November 2013, II SA/Wa 909/13.

${ }^{20}$ See judgement of the Voivodeship Administrative Court in Bydgoszcz of 7 August 2019, II SA/Bd 184/19; judgement of the Voivodeship Administrative Court in Poznań of 10 October 2013, IV SA/Po 467/13. 
Thus, a prerequisite for recognizing the existence of an entrepreneur's secret is "to indicate specific information of economic value belonging to him which is to benefit from confidentiality"21.

Moreover - in accordance with the above-mentioned judgement of the Voivodeship Administrative Court in Warsaw of 15 November 2013 (II SA/Wa 909/13) - to confirm the existence of a legally protected business secret, it should be demonstrated that the information in question, first, was not previously disclosed to the public; secondly, it has technical, technological, organizational, commercial or economic value; and, thirdly, specific actions have been taken (by the entrepreneur) to preserve its confidentiality. In addition, the above judgement shows that in order to extract information that may constitute an entrepreneur's secret, the entity obliged to disclose it should examine whether in fact all data reserved by the entrepreneur is such a secret, and to do so, one cannot justify refusing to disclose information based solely on a declaration of intent the same entrepreneur, but on objective arguments for qualifying specific information to specific categories of data that may constitute a secret.

It is also impossible not to pay attention to the connection between the assessment of the issue of "entrepreneur's secret" and the constitutional principle of proportionality. It is claimed that the right to secrecy should be protected by law proportionally more important from the point of view of the citizen's interest and social interest. For example, the Supreme Administrative Court pointed out in one of its judgements that:

[...] considering the constitutional rank of access to public information, not every entrepreneur's secret will justify a refusal to disclose it. The significance of a given secret must be proportionally greater than the reasons for disclosing public information. Restrictions on economic freedom and weighting criteria for conflicting values are assessed from the point of view of the proportionality mechanism (Article 31 (3) of the Polish Constitution). By defining the constitutional freedoms and rights of the citizen, the legislator sees the need to introduce restrictions on these goods. The legislator puts one constitutional good over another, thus setting boundaries for exercising freedom and rights, creating a kind of hierarchy of goods that falls within their constitutional relations. It is, therefore, a question of properly balancing the proportions that must be observed to assume that a given restriction on civil liberties does not violate the constitutional hierarchy of goods (principle of proportionality $)^{22}$.

Another interpretative problem that is worth to pay attention to is the scope of the meaning of the term "public property" used in the Act on Access to Public Information, and hence the answer to the question whether all information regarding any (every) asset of the State Treasury and local government is to be disclosed.

${ }^{21}$ See judgement of the Voivodeship Administrative Court in Łódź of 9 June 2014, II SAB/Łd 50/14.

${ }^{22}$ See judgement of the Supreme Administrative Court 12 February 2015, I OSK 759/14. 
The current achievements of doctrine and jurisprudence allow for an extremely broad understanding of the concept of "property" as the total rights and obligations of a given entity. I. Kamińska and M. Rozbicka-Ostrowska include public property, including other property rights of the state and its debts. In the understanding of these authors, this will be information about real estate, movables and other property rights, as well as rights on intangible assets, shaped as absolute rights or relative obligations. This concept is defined in case law in a similar broad way. For example, the Voivodeship Administrative Courts in Warsaw and Olsztyn indicate that data on the rules for the use of cars by public authorities and organizational units performing public tasks as well as information on the authority's indication of the category of a given road within the meaning of the Act on Public Roads are subject to disclosure. Administrative courts also refer (they indicate that they are property rights) to the "list of connections for the indicated period (billing) of all business telephones at the disposal of the city hall"23.

A fairly significant problem in the practice of applying the Act on Access to Public Information is also the issue of timely access to information, and hence problems related to the definition of transformed information and the determination of the costs of proceedings.

First of all, it should be noted that Article 13 (1) of the Act on Access to Public Information sets out the deadline for providing public information as immediate, but not longer than 14 days from the date of submission of the application, except if the information cannot be made available within the specified time limit, and the entity obliged to provide it will notify the other party about that date (and the reasons for the delay), setting a new date (no longer than 2 months from the date of submission of the application). The Act on Access to Public Information provides for an extension of the deadline for disclosing information also when the entity obliged to provide public information is to incur additional costs related to the method of disclosing or transforming the information indicated in the application.

Therefore, analysing the concept of "transformation" it should be noted that the Act on Access to Public Information uses both the concepts of "processed" and "transformed" information, without defining these concepts. They have, however, been explained in the doctrine. According to the opinion of M. Jabłoński and $\mathrm{K}$. Wygoda, "processing" is an action on the information itself (by changing the already existing information), while "transformation" is only an action taken on the information, with the processing being the intellectual effort of the person seeking to receive a certain result based on already available data, and the transformation

${ }^{23}$ See judgement of the Voivodeship Administrative Court in Warsaw of 23 May 2007, II SA/ Wa 875/06; judgement of the Voivodeship Administrative Court in Olsztyn of 17 April 2008, II SAB/ Ol 10/08. 
only involves a purely technical procedure and refers only to the external form of the given document or statement ${ }^{24}$.

However, when referring to the costs of providing information, it should be pointed out that the legislator generally assumes free access to public information. The provision of Article 7 (2) of the Act on Access to Public Information specifies that access to public information is free, subject to Article 15. However, in relation to Article 15 of the Act, it is clear that the applicant may be charged additional costs related to the way information is made available or transformed. Therefore, without doubt, it is unlawful to make the acceptance of the application (or its implementation) conditional upon payment of any fee. These costs relate only to two types of components: material (understood as the material or medium on which the information was recorded) and personal (work of a person who was specifically delegated to fulfil the task of "saving" in a certain form).

The only noticeable problem regarding the costs of providing information, occurring in practice (mainly due to the lack of statutory regulation), is the definition of the form of the act determining the amount of the fee for actions taken (in this respect) by the administration. Therefore, current court and administrative case-law is of particular importance. It indicates, among others, that determining the amount of the fee should, in principle, be considered as an act in the field of public administration. The courts state that no form of order is provided for this activity. Rather, it is an act in the field of public administration, referred to in Article $3 \S 2$ (4) of the Act of 30 August 2002 - Law on Proceedings Before Administrative Courts ${ }^{25}$. In jurisprudence, a view prevails that the Act on Access to Public Information, when it comes to charging for information provided, does not refer to the provisions of the Code of Administrative Procedure. Therefore, the Act does not determine the procedure (mode) for its collection, nor does it require the application of the provisions of Section IX of the Code of Administrative Procedure (concerning costs of proceedings). Thus, it can be confirmed that the provisions of the administrative procedure are directly applicable to matters of access to public information only in strictly defined situations, i.e. when issuing decisions refusing public information or decisions discontinuing the initiated proceedings ${ }^{26}$. Moreover, it is claimed that the act determining the above fee has a public law nature because it affects the situation of a particular legal entity in a legally binding manner. At the same time, an act of this type concerns a right or obligation under a law ${ }^{27}$. Therefore, it can be

${ }^{24}$ M. Jabłoński, K. Wygoda, Ustawa o dostępie do informacji publicznej, Wrocław 2002, p. 32.

25 Journal of Laws 2018, item 1302 as amended.

${ }^{26}$ Cf. judgement of the Supreme Administrative Court of 5 February 2008, I OSK 581/07, LEX No. 357786; decision of the Supreme Administrative Court of 25 October 2012, I OSK 2359/12; judgement of the Voivodeship Administrative Court in Poznań of 12 September 2012, IV SA/Po 475/12; decision of the Voivodeship Administrative Court in Gdańsk of 16 January 2012, II SA/Gd 646/12.

${ }^{27}$ Decision of the Supreme Administrative of 1 October 2013, I OSK 2139/13. 
considered that the most commonly used form of the "provision on determining the costs of making public information available" should be regarded as another letter which is not an order or an administrative decision.

Summarising the considerations made, it should be confirmed that the current achievements of doctrine and jurisprudence allow for an effective and specific interpretation of the law regarding the provision of public information. Although in this study we have presented only a fragment of the issues related to the application of the Act on Access to Public Information, the literature cited, and above all the case law of administrative courts and the Constitutional Tribunal, allow for clarification of disputable interpretation issues regarding both answers to questions about the scope of the concept of public information, types of entities required to disclose it, circumstances in which it is possible to talk about limiting the right to information due to the privacy of a natural person or the secret of the entrepreneur, as well as the form of determining the costs of the procedure leading to the disclosure of public information.

\section{REFERENCES}

\section{Literature}

Jabłoński M., Wejście w życie ustawy o dostępie do informacji publicznych, „Przegląd Prawa i Administracji” 2002, nr 51.

Jabłoński M., Wygoda K., Ustawa o dostępie do informacji publicznej, Wrocław 2002.

Kamińska I., Rozbicka-Ostrowska M., Komentarz do art. 6 ustawy o dostępie do informacji publicz$n e j, \mathrm{LEX} / \mathrm{el}$.

Sitniewski P., Ustawa o dostępie do informacji publicznej. Komentarz, Wrocław 2011.

Stefanicki R., Ustawa o dostępie do informacji publicznej. Wybrane zagadnienia w świetle orzecznictwa sądowego, „Państwo i Prawo” 2004, z. 2.

\section{Legal acts}

Act of 16 April 1993 on Combating Unfair Competition (Journal of Laws 2019, item 1010 as amended).

Act of 6 September 2001 on Access to Public Information (Journal of Laws 2019, item 1429).

Act of 30 August 2002 - Law on Proceedings Before Administrative Courts (Journal of Laws 2018, item 1302 as amended).

Regulation (EU) 2016/679 of the European Parliament and of the Council of 27 April 2016 on the protection of natural persons with regard to the processing of personal data and on the free movement of such data, and repealing Directive 95/46/EC (General Data Protection Regulation) (OJ EU L 2016.119.1 of 4 May 2016). 


\section{Case law}

Decision of the Supreme Administrative Court of 11 December 2002, II SAB 105/02, LEX No. 137863.

Decision of the Supreme Administrative Court of 25 October 2012, I OSK 2359/12, http:/orzeczenia. nsa.gov.pl/doc/44C3912F2D [access: 10.10.2020].

Decision of the Supreme Administrative of 1 October 2013, I OSK 2139/13, http://orzeczenia.nsa. gov.pl/doc/AA4DA80D9F [access: 10.10.2020].

Decision of the Voivodeship Administrative Court in Gdańsk of 16 January 2012, II SA/Gd 646/12, https://sip.lex.pl/orzeczenia-i-pisma-urzedowe/orzeczenia-sadow/ii-sa-gd-646-12-postanowienie-wojewodzkiego-sadu-521372885 [access: 10.10.2020].

Judgement of the Constitutional Tribunal of 20 March 2006, K 17/05, http://prawo.sejm.gov.pl/isap. nsf/DocDetails.xsp?id=WDU20060490358 [access: 10.10.2020].

Judgement of the European Court of Human Rights of 8 November 2016, Magyar Helsinki Bizottság (Hungarian Helsinki Committee) vs Hungary, Application No. 18030/11, https://hudoc.echr.coe. int/eng\#\{\%22itemid\%22:[\%22001-167828\%22]\} [access: 4.12.2019].

Judgement of the Supreme Administrative Court of 20 June 2002, II SAB 70/02, www.orzeczenia-nsa. pl/wyrok/ii-sab-70-71-02/sprawy_nieobjete_symbolami_podstawowymi_oraz_od_dostep_do_ informacji_publicznej/24301c3.html [access: 10.10.2020].

Judgement of the Supreme Administrative Court in Wrocław of 5 December 2002, II SA/Wr 1600/02.

Judgement of the Supreme Administrative Court of 2 July 2003, II SA 837/03, http://orzeczenia.nsa. gov.pl/doc/05039159BA [access: 10.10.2020].

Judgement of the Supreme Administrative Court of 5 February 2008, I OSK 581/07, LEX No. 357786.

Judgement of the Supreme Administrative Court of 5 July 2013, I OSK 511/13, http://orzeczenia. nsa.gov.pl/doc/4E91674864 [access: 10.10.2020].

Judgement of the Supreme Administrative Court 12 February 2015, I OSK 759/14, http://orzeczenia. nsa.gov.pl/doc/8BB313D2AD [access: 10.10.2020].

Judgement of the Supreme Administrative Court of 13 October 2016, I OSK 3451/15, https://sip.lex. pl/orzeczenia-i-pisma-urzedowe/orzeczenia-sadow/i-osk-3451-15-wyrok-naczelnego-sadu-administracyjnego-522349996 [access: 10.10.2020].

Judgement of the Supreme Administrative Court of 14 April 2017, I OSK 872/15, www.orzeczenia-nsa.pl/wyrok/i-osk-872-15/sprawy_z_zakresu_informacji_publicznej_i_prawa_prasowego_dostep_do/fe8e0e.html [access: 10.10.2020].

Judgement of the Supreme Administrative Court of 7 March 2019, I OSK 888/17, https://sip.lex.pl/ orzeczenia-i-pisma-urzedowe/orzeczenia-sadow/i-osk-888-17-wyrok-naczelnego-sadu-administracyjnego-522809234 [access: 10.10.2020].

Judgement of the Voivodeship Administrative Court in Gliwice of 29 March 2004, II SAB/Ka 144/03, http://orzeczenia.nsa.gov.pl/doc/E3EA1C74F5 [access: 10.10.2020].

Judgement of the Voivodeship Administrative Court in Warsaw of 24 March 2006, II SAB/Wa 1/06, LEX 197599.

Judgement of the Voivodeship Administrative Court in Warsaw of 23 May 2007, II SA/Wa 875/06, www.orzeczenia-nsa.pl/wyrok/ii-sa-wa-875-06,sprawy_z_zakresu_informacji_publicznej_i_prawa_prasowego, 15af499.html [access: 10.10.2020].

Judgement of the Voivodeship Administrative Court in Warsaw of 22 June 2007, II SAB/Wa 175/06, LEX 340013.

Judgement of the Voivodeship Administrative Court in Olsztyn of 17 April 2008, II SAB/O1 10/08, www.orzeczenia-nsa.pl/wyrok/ii-sab-ol-10-08/sprawy_z_zakresu_informacji_publicznej_i_prawa_prasowego_administracyjne_postepowanie_dostep_do/e58bfe.html [access: 10.10.2020]. 
Judgement of the Voivodeship Administrative Court in Poznań of 12 September 2012, IV SA/Po 475/12, https://sip.lex.pl/orzeczenia-i-pisma-urzedowe/orzeczenia-sadow/iv-sa-po-475-12-wyrok-wojewodzkiego-sadu-521316147 [access: 10.10.2020].

Judgement of the Voivodeship Administrative Court in Gdańsk of 11 September 2013, II SA/Gd 503/13, http://orzeczenia.nsa.gov.p1/doc/2DB8B07FD4 [access: 10.10.2020].

Judgement of the Voivodeship Administrative Court in Poznań of 10 October 2013, IV SA/Po 467/13, ww.orzeczenia-nsa.pl/wyrok/iv-sa-po-467-13/sprawy_z_zakresu_informacji_publicznej_i_prawa_prasowego_dostep_do/209fb45.html [access: 10.10.2020].

Judgement of the Voivodeship Administrative Court in Warsaw of 15 November 2013, II SA/Wa 909/13, https://sip.lex.pl/orzeczenia-i-pisma-urzedowe/orzeczenia-sadow/ii-sa-wa-909-13-informacja-publiczna-w-postaci-kopii-521502395 [access: 10.10.2020].

Judgement of the Voivodeship Administrative Court in Łódź of 9 June 2014, II SAB/Ld 50/14, http:// orzeczenia.nsa.gov.p1/doc/482BB8C7D5 [access: 10.10.2020].

Judgement of the Voivodeship Administrative Court in Gdańsk of 11 June 2014, II SA/Gd 5/14, www. lexlege.pl/orzeczenie/29328/ii-sa-gd-5-14-wyrok-wojewodzki-sad-administracyjny-w-gdansku [access: 10.10.2020].

Judgement of the Voivodeship Administrative Court in Kraków of 2 September 2014, II SA/Kr 940/14, www.orzeczenia-nsa.pl/wyrok/ii-sa-kr-940-14/sprawy_z_zakresu_informacji_publicznej_i_prawa_prasowego/e011ff.html [access: 10.10.2020].

Judgement of the Voivodeship Administrative Court in Warsaw of 18 January 2019, II SAB/Wa 612/18, www.orzeczenia-nsa.pl/wyrok/ii-sab-wa-612-18/33ef42b.html [access: 10.10.2020].

Judgement of the Voivodeship Administrative Court in Gdańsk of 5 June 2019, II SAB/Gd 34/19.

Judgement of the Voivodeship Administrative Court in Bydgoszcz of 7 August 2019, II SA/Bd 184/19, https://sip.lex.pl/orzeczenia-i-pisma-urzedowe/orzeczenia-sadow/ii-sa-bd-184-19-przeslankiodmowy-udostepnienia-522815659 [access: 10.10.2020].

\section{STRESZCZENIE}

Przepisy ustawy o dostępie do informacji publicznej regulują m.in. zakres podmiotowy i przedmiotowy prawa do informacji publicznej, przyczyny ograniczenia udostępnienia informacji, procedurę i formę udostępniania, zasady tworzenia i publikowania informacji w Biuletynie Informacji Publicznej, koszty działań prowadzących do udostępnienia informacji oraz założenia postępowania skargowego w przypadku odmowy udostępnienia żądanych informacji publicznych. Warto zwrócić uwagę na kilka problemów wynikających z analizy przepisów ustawowych oraz na konsekwencje praktyczne stosowania ustawy z dnia 6 września 2001 r. o dostępie do informacji publicznej. Dotychczasowy, niezwykle już obszerny dorobek doktryny i judykatury pozwala na dość „sprawne” podsumowanie rozważań poczynionych zarówno w literaturze, jak i orzecznictwie sądowo-administracyjnym.

Słowa kluczowe: informacja publiczna; informacja przekształcona; funkcjonariusz publiczny 